\title{
PENEMUAN BENIH-BENIH MAQAASHID AL-SHARI'AH PADA MASA SAHABAT
}

\author{
lsnaini \\ Universitas Islam Negeri Imam Bonjol Padang \\ Isnainikhalil@gmail.com
}

Naskah diterima: 25 Januari 2021, direvisi: 30 Maret 2021, disetujui: 10 Juni 2021

\section{Abstrak}

The article wants to explain about the discovery of the seeds of the application of maqashid al-shariah as one of the methods of formulating Islamic law at the time of the Companions. This study uses a descriptive analytical method with the type of library research with a historical philosophical approach. The results of the study found and proved that in practice maqashid al-shariah had been applied in the formulation of laws on various problems, even though at that time maqashid al-shariah had not yet become an independent science or a branch of usul al-fiqh. The form of legal formulation based on maqashid al-shari'ah can be seen in the following examples between choosing the time of prayer on the way, distribution of spoils of war, zakat for people who have just converted to Islam, and the punishment of cutting off hands for thieves during times of famine.

Keywords: maqashid Al-shari'ah, Companions, usul al-fiqh

\begin{tabular}{|c|}
\hline Abstrak \\
\hline $\begin{array}{l}\text { Artikel ingin menjelaskan tentang penemuan benih-benih penerapan maqashid al- } \\
\text { shari>ah sebagai salah satu metode perumusan hukum lslam pada masa sahabat. } \\
\text { Penelitian ini menggunakan metode deskriptif analitis yang berjenis penelitian } \\
\text { kepustakaan (library research) dengan pendekatan filosofis historis. Hasil penelitian } \\
\text { menemukan dan membuktikan bahwa secara praktek maqashid al-shariah telah } \\
\text { diterapkan dalam perumusan hukum terhadap berbagai masalah, walaupun ketika itu } \\
\text { maqa>shid al-shari>'ah belum menjadi sebuah ilmu mandiri atau cabang usul al-figh. } \\
\text { Bentuk perumusan hukum berdasarkan maqashid al-shari'ah itu dapat dilihat pada } \\
\text { contoh-contoh berikut antara memilih waktu pelaksanaan shalat dalam perjalanan, } \\
\text { disrtibusi harta rampasan perang, zakat untuk orang yang baru masuk lslam, serta } \\
\text { hukuman potong tangan untuk pencuri ketika masa panceklik. }\end{array}$ \\
\hline
\end{tabular}

Kata Kunci: maqashid Al-shari'ah, Shahabat, usul al-fiqh 


\section{PENDAHULUAN}

Penelitian ini dilatarbelakangi pertanyaan apakah perumusan hukum Islam di zaman memakai pendekatan atau menggunakan sumber maqashid alshariah. Banyak persoalan yang yang terjadi di zaman sahabat tidak diselesaikan berdasarkan makna lahir (tekstual) ayat bahkan cenderung diluar teks (kontekstual). Karenanya, penelitian ini ingin membuktikan apakah setiap perumusan hukum dalam ijtha>d sahabat itu sesuai dengan tujuan, rahasia dan hikmah dari pembuat hukum (al-shari).

\section{METODE PENELITIAN}

Penelitian ini tergolong sebagai penelitian kepustakaan yang menjadikan teks sebagai objek penelitian. Mengingat penelitian ini adalah penelitian kualitatif, maka salah satu metodenya adalah dokumentasi yang diterapkan dengan cara menghimpun dokumen pribadi maupun dokumen resmi yang diperoleh dari kepustakaan. Pengolahan data menggunakan metode deskriptif analitis yang berguna untuk mendeskripsikan dan menganalisis penerapan teori maqashid al-shariah dan penerapannya di zaman sahabat. Secara garis besar penelitian ini menggunakan pendekatan filosofis dan historis. Pendekatan filosofis bertujuan untuk mengungkapkan esensi perumusan hukum ketika sahabat berijtihad baik secara ontologis, epsitemilogis dan aksiologis. Pendekatan historis bertujuan menggambarkan secara waktu dan tempat dimana dan kapan terjadinya penerapan maqashid alshariah.

HASIL PENELITIAN DAN

\section{PEMBAHASAN}

\section{Defenisi Maqashid al-shari'ah}

Secara bahasa maqashid al-shariah terurai dari dua kata, maqashid dan shariah. Maqashid adalah bentuk plural dari kata مقصد dengan fathah huruf shad, yang berasal dari kata قصد yang diderivasi dari kata قصد-يقصد_قصدا yang mempunyai arti bermaksud, menuju suatu tujuan, tengah-tengah, adil, tidak melewati batas, dan jalan yang lurus. (Abadi, Fairuz, 1987, 396 dan Munawwir, Warson, 1997,1123-1124). Arti kata ini sejalan dengan berbagai akar kata maqashid yang terdapat dalam berbagai firman Allah dalam al-Quran. Misalkan dalam QS. Fathir, ayat 32 yakni:

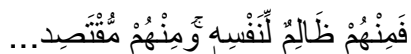

Artinya:

...lalu di antara mereka ada yang menzalimi diri sendiri, ada yang pertengahan... (QS.Fathir, 35 :32).

$$
\text { llyas Dardur menyebutkan }
$$

bahwa kata maqa>shid mempunyai lima arti yaitu: الإعتدال والتوسط وعدم الإفراط(1) 
(seimbang dan tidak melewati batas), (2) (konsisten dalam menempuh jalan), (الوسط (3) (seimbang),

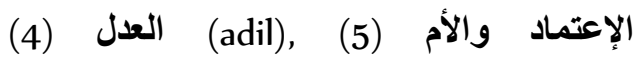
(pegangan dan menyengaja). (Dardur, llyas, 2015, 7-9).

Sedangkan unsur kedua adalah lafaz shariah yang secara bahasa mempunyai arti jalan menuju mata air, kebiasaan, sunnah, jalan, adat kebiasaan, sama. (Munawwir, Warson, 1997, 711). Sedangkan menurut istilah banyak sekali terminologi ulama. Dalam perspektif "lzz al-Di>n lbn 'Abd al-Sala>m, shariah adalah: الثريعة هو المنهج المستقيم ومورد الأحكام المنظمة الذي ارتضاه الله لعباده. (Syari'ah adalah jalan yang lurus dan aturan yang yang disukai oleh Allah untuk sekalian hambanya). (Zahgibah, al-Din, 1999, 39).

Apabila kata maqasshid dan alshariah digabungkan maka para ulama ushul telah memberikan banyak defenisinya. Misalnya menurut 'Alla>l alFa>si adalah: الغاية منها والأسرار التى وضعها الثارع عند كل حكم من أحكامها. (berbagai tujuan dan rahasia dari shariah yang ditetapkan Allah ketika menetapkan suatu hukum di antara berbagai hukum). ('Abdullah, 'Allal, 1963, 51). Nur al-Din menggarisbawahi beberapa komponen dasar yang harus ada dalam maqashid al-shariah yaitu: (1) mesti mencakup tujuan dan rahasia yang hendak dicapai, (2) hukum shari'at, (3) seluruh tujuan dan rahasia yang diingini harus bermuara pada nilai ketaatan atau 'ubudiyyah kepada Allah, (4) tujuan dan rahasia itu adalah mashlahah bagi manusia di dunia dan akhirat. (Al-khadimi. Nur, 2008, 14; Isnaini, 2018, 206-218).

\section{Peran Maqashid al-Shariah Antara}

\section{Sebagai Sebuah Sumber dan Pendekatan}

Mayoritas ulama, baik ulama klasik ataupun kontemporer sepakat bahwa tujuan syariat Islam untuk kemaslahatan manusia baik di dunia dan akhirat. Semua perintah dan larangan mempunyai hikmah dan manfaat bagi pelakunya. (Darraz, Abdullah, t,t. 3).

Berdasarkan ini, setiap ulama sepakat maqashid al-hariah adalah aspek terpenting dalam penetapan hukum. Setiap hukum tidak boleh keluar dari dimensi maqa>shid alshari>ah. Oleh karena mengetahui maqashid al-shariah adalah persyaratan utama bagi mujtahid. (Al-Najjar, 'Abdul Ma>jid, 2008, 20 dan $A l-$ raisu>ni, Ahmad, 1995, 353-362).

Para Maqashidiyyun telah ijma $>\mathrm{k}$ bahwa syari'at mempunyai maksud dan tujuan (maqashid al-shariah), namun realitanya mereka tidak sepakat mengenai status, posisi dan fungsi maqashid al-shariah itu sendiri. Mereka 
senantiasa mempersoalkan apakah maqa>shid al-shariah dapat dikatakan sebuah ilmu yang mandiri, yang berdikari ("ilm mustaqil), terpisah dari usu>l al-fiqh, atau dia masih menjadi bagian teori usu>l al-figh dalam merespon berbagai persoalan hukum. Perspektif ulama terkait permasalahan ini dapat dikelompokan dalam tiga kategori, yakni: maqashid al-shariah sebagai teori merdeka, maqashid alshariah sebagai bagian dari usul alfigh, maqashid al-shariah dan usul alfigh sebagai teori yang saling menyempurnakan. Berikut uraian lengkapnya.

\section{Maqashid al-Shariah Sebagai Teori lndependen}

Thahir Ibn 'Ashur mempresentasikan tentang wacana kemerdekaan maqa>shid al-shariah untuk pertama kali melalui karyanya yang berjudul maqashid al-shariah al-lsla>miyyah. la memaparkan:

"Jikalau kita ingin menggali sebuah pengetahuan yang absolut (qath'i) untuk mendapatkan pemahaman keagamaan, menjadi keniscayaan bagi kita untuk mengerti secara mendalam berbagai permasalahan usul al-figh, kemudian dibentuk ulang sembari diuji dengan menerapkan penalaran kritis, lalu kita lenyapkan semua unsur aneh yang menjadi anomali-anomali. Setelah itu, kita berikan pengayaan di dalamnya, ilmu yang sangat utama di dalam kajian figh. Kita beri nama ilmu baru ini dengan ilmu maqashid al-shariah dan kita abaikan usul al-figh sebagaimana adanya. (Ibn 'Ashur, 2006, 49).

Pernyataan diatas muncul, disebabkan keprihatinan yang mendalam terhadap perpecahan, konflik dan ketidaksamaan pendapat yang terjadi dalam menetapkan hukum Islam. Kesukaran mencari titik temu karena argumentasi yang dibangun umat Islam, tidak dibangun dari berbagai prinsip syariat dan tidak mengacu kepada tujuan shariah. Ahli syariat perlu menciptakan metode yang akurat, absolut dan memiliki kebenaran universal yang dapat diterima loleh mayoritas orang. Ahli syari'at harus bisa menciptakan metode tersebut, sebagaimana para sainstis mampu menggali pengetahuan yang absolut, minimal mengarah kepada kepastian dan tidak menimbulkan konflik. (lbn 'Ashur, 2006, 3-4). Walaupun pengetahuan yang absolut terbilang pelik untuk dirumuskan, akan tetapi secara minimal, pengetahuan yang mendekati kepastian mampu diformulasikan oleh ahli syariat. (Ferdiansyah, Hengki, 2017, 55).

Untuk menjadi sebuah ilmu baru yang berdiri sendiri, sebenarnya dalam 
perspektif 'Abd al-Majid al-Shagi>r, maqashid sudah diwacanakan oleh alJuwaini sedari tempo dulu. llmu baru ini diharapkan dapat menimalisir perdebatan dan polemik di kalangan ulama dan melewati usul al-figh yang masih berkarakter zanni. (Al-shagir, 'Abd al-Majid, 1994, 55). Namun, Nu'man Jughaim mengkritisi kesimpulan ini. Menurutnya, al-Juwaini tidak menghendaki menjadikan maqashid alshari'ah sebagai ilmu yang merdeka dan dia sekedar membuat rumusan kaidahkaidah universal syariat yang dapat dibuat menjadi rambu-rambu dalam penetapan hukum. Ditambahkan lagi oleh Nu'man Jughaim, bahwa pernyataan yang dilontarkan oleh alJuwaini pada saat itu, karena tidak berfungsinya struktur sosial, politik dan dunia yang sedang diterpa bencana krisis ulama. Dalam situasi krisis seperti ini, tidak banyak orang yang punya kompetensi dan kapabilitas dalam berijtihad yang mampu menerapkan rumusan usul al-figh lama secara paripurna, merdeka dan memberikan hasil, manfaat serta signifikansi. (Jughaim, Nu'man, 2007, 69). Supaya produk hukum yang mereka lahirkan tidak kebablasan alias tidak meleset jauh dari prinsip pokok syari>at perlu kiranya digali kode etik syari>at. (Jughaim, Nu'ma>n, 2007, 69).
'Abd al-majid al-Najjar kelihatannya juga mensupor gagasan independensi (kemerdekaan) maqa>shid dari usul al-figh. Pada saat mengeksplorasi perkembangan diskursus maqashid al-shariah, dia mengakui bahwa diskursus maqashid alshariah pada zaman kontemporer ini, perhatiannya sudah beralih kepada usaha menjadikannya sebagai disiplin ilmu yang merdeka (mandiri) yang memiliki perbedaan dari usul al-figh. Hal ini tergambar dari berbagai karya ulama kontemporer, hasil riset, bahkan saat ini maqa>shid sudah ditetapkan menjadi mata kuliah dan jurusan tersendiri di berbagai kampus Timur Tengah. (Al-najjar, 'Abdul al-Majid, 2008, 23).

\section{Maqashid al-Shariah Sebagai Elemen Usul al-figh}

Perdebatan dan polemik di kalangan ulama dan akademisi ditimbulkan oleh wacana pemisahan maqashid dari usul al-figh dan manjadikan ilmu yang berdiri sendiri ('ilm mustaqi). Perspektif sebahagian mereka, maqashid tidak dapat berdiri sendiri sendiri karena hakikatnya ia adalah bahagian dari ilmu usul al-figh. Pendapat ini terhubung kepada komentar 'Abdullah bin Daraz yang menyatakan bahwa istinbat hukum dapat diupayakan melalui dua ilmu: kaidah bahasa 'Arab 
('ilm lisan al-'Arab) dan ilmu rahasia syari'at (asrar al-shariah). (Daraz, 'Abdullah, t,t, 4). Kedua ilmu ini dalam persepekstif al-Raisuni terintergrasi dalam kajian usul al-fiqh. Artinya, usul al-figh tidak hanya mencakup berbagai teori kebahasaan, namun juga membahas secara detail tentang rahasia, maksud dan tujuan syari'at.

Tiga kritikan yang dilontarkan ALHasan al-Shahi>d terhadap kelompok yang mendukung maqashid al-shariah. Pertama, dengan hadirnya kajian khusus tentang maqashid al-shariah dalam berbagai karya ulama kontemporer, itu tidak berarti mengisyaratkan kemandirian maqashid al-shariah yang berdiri sendiri dan terpisah begitu saja dari usul al-figh. Sebab, ulama terdahulu juga banyak menulis buku spesifik yang berkaitan dengan berbagai teori yang terdapat dalam usul al-figh, namun kehadiran karya tersebut tidak mesti dipahami sebagai teori yang merdeka (independen) dan terceraikan dari induknya. Seperti bahasan ijtihad yang ditulis oleh al-Juwaini dan alSuyu>thi dalam satu buku khusus. Hal ini bukan berarti mereka ingin menceraikan ijtihad dari kerangaka besar teori usul al-figh, karena setiap ilmu mempunyai banyak bagian dan cabang, dan sering seorang ulama ingin memperinci secara detail salah satu bahagian ilmu tersebut dalam satu bentuk buku khusus. (Shahi>d, alShahid, 2013, 79).

Kedua, usul al-figh secara metodologis hakikatnya sama dengan maqashid al-shariah, sebab usul al-fiqh juga sebuah metode untuk memperoleh pemahaman akan maksud dan tujuan Tuhan dalam setiap perintah dan larangannya. Ada kejanggalan yang dirasakan oleh 'Abd al-Qadi>r lbn Hirzillah bila maqa>sid disebut sebagai solusi alternatif dari tekstualitas usu>l al-figh, karena pada subtansinya asumsi yang diciptakan banyak orang bahwa maqa>shid itu berdiri pada dalil universal (al-kulliyya $>t)$ dan dalil yang absolut (al-qath'iyyat). Keseluruhan ini merupakan hasil dari pemikiran ulama usul al-figh. Bahkan diera modern maqashid al-shariah telah diangkat ke permukaan lagi, tidak jauh perbedaannya dengan maqa>shid yang telah dikontruksi ulama klasik dalam berbagai buku usul al-figh. (Ibn Hirzillah, 'Abd al-Qad>r, 2007, 318320).

Ketiga, realitanya jika ditelaah berbagai buku maqashid saat ini, hampir keseluruhan buku itu membahas berbagai teori yang telah lama diterapkan dalam usul al-figh seperti istiqra>', mashlahah al-mursalah, istihsa>n , masalik al-illah, qiya>s, dan 
lain sebainya. Dengan demikian, dalam ranah praktis dan konsep antara usu>l al-figh dan maqashid memang tidak dapat diceraikan. (Shahid, al-Shahid, 2013, 80).

Sementara itu Jamal al-Din al'Athiyyah tidak begitu percaya seberapa besar manfaat yang didapat dari usaha penceraian kedua pengetahuan ini, bahkan usaha tersebut, yang pada akhirnya akan menimbulkan kerugian kedua belah pihak jika tetap dipaksakan. Dalam pandangannya, usul al-figh akan menghadapi stagnasi jika diceraikan dari kajian maqashid al-shari'ah, karena maqa>shid adalah jantung usul al-figh itu sendiri. Begitu pula sebaliknya, maqashid al-shari'ah tidak akan berguna dan beroperasi, bila tidak disertai dengan usul al-fiqh, sebab kebanyakan metode yang diterapkan di dalamnya masih memakai dari teori usul al-figh. (Al-'Athiyyah, Jamal al-Din, 2006, 238). Selaras dengan pendapat sebelumnya, 'Abdullah bin Bayah lebih cenderung kepada pengoptimalan maqashid alshari>ah dalam diskursus usul al-figh. Bahkan la juga bisa diterapkan untuk mengembangkan konsep istihsan, istishlah, qiyas, ma"alat al-afal, sad aldzara>i, yang selama ini terlihat kaku dan didominasi dengan persyaratan teknis yang sangat ketat. (lbn Ba>yah, Abdullah, 2006, 137).
Kesimpulan kelompok ini dimulai dari fakta historis yang menjelaskan bahwa maqashid al-shariah adalah pengetahuan yang lahir dari Rahim usul al-figh dan tidak mungkin menceraikan keduanya. (Shahid, al-Shahid, 2013, 85). Hal ini dapat dibuktikan dengan berbagai teori dan terminologi usul alfigh yang juga diterapkan dalam kajian maqashid al-shariah. Maka dari itu, alShatibi tidak menyatukan pembahasannya dalam karyanya almuwafaqat, karena antara keduanya dalam ranah teoritis dan praktis sangat mempunyai keterkaitan. (Jughaim, Nu'man, 2007, 57-64).

Maqashid al-Shariah dan Usu>l al-Figh Sebagai Teori yang Saling Menyempurnakan

Sekalipun pada mulanya maqa>shid al-shariah hanya bagian dari konsep usul al-figh dan penerapannya juga banyak didapati dalam berbagai literatur figh, namun tidak dapat dijadikan alasan untuk mengkrangkeng maqashid alshariah selamanya dalam jeruji besi usu>l al-figh. Sudah menjadi kebiasaan dalam perkembangan ilmu pengetahuan bahwa suatu ilmu dimulai dengan konsep tertentu, kemudian dikaji dan diperiksa terus-menerus sampai akhirnya menjadi ilmu yang mapan dan merdeka (berdiri sendiri). Banyaknya kajian, riset dan dibukanya 
jurusan/konsentrasi maqashid al-shari'ah di sejumlah perguruan tinggi Islam, ini memberikan sinyalemen bahwa kelayakan maqa>shid al-shariah untuk disejajarkan dengan berbagai ilmu keislaman lainnya. (Al-Khadimi, Nur alDin, 2007, 59).

Salah cara yang dapat diterapkan untuk membuktikan kelayakan maqashid al-shariah menjadi sebuah ilmu yang yang memiliki distingsi dengan ushul al-figh adalah dengan melakukan pengujian dimensi ontologis, epistemilogis, dan aksiologis yang terhimpun di dalamnya. Ketiga dimensi ini adalah parameter dasar dalam filsafat ilmu, guna melihat perbedaan cakupan satu ilmu dengan ilmu lainnya dan bisa juga diterapkan untuk memberikan sebuah penilaian apakah objek yang dikaji itu pantas disebut sebagai sebuah ilmu atau sebaliknya. lsma'il al-Hasan dalam risetnya terhadap pemikiran maqashid al-shari>ah lbn 'Ashur, memberikan kesimpulan bahwa maqa>shid al-shari'ah layak disebut ilmu karena sudah mencakup ketiga dimensi tersebut. (Al-Hasani, Isma'il, 1995, 120128). Uraian rinci dari ketiga dimensi tersebut adalah sebagai berikut:

Pertama, dilihat dari dimensi ontologis (maudhui), maqashid alshariah terdiri dari disiplin berbagi ilmu memuat prinsip, berbagai kaidah dan berbagai metode yang dapat diterapkan untuk mendapatkan pemahaman tentang maksud dan tujuan syari>at. Oleh karena itu, tidak aneh bila sebagian objek yang dibahas dalam kajian ini adalah pengembangan lebih lanjut dari berbagai materi yang sudah didiskusikan dalam ushul al-figh dan qawa'id fiqhiyyah. (Al-Hasani, Isma'il, 1995, 125). Kedua, dilihat dari dimensi metodologis (al-manhaj), maqa>shid alshariah sudah mempunyai aneka ragam metode yang dapat diterapkan untuk menelusuri hikmah yang tertulis dan yang tersirat dalam teks. Salah satu metode yang biasa mereka pakai adalah metode istiqra'. (Al-hasani, Ismail, 1995, 437). Sementara dari dimensi aksiologis, tujuan ilmu maqashid alshariah adalah menemukan hikmah dan rahasia yang tersimpan dalam syari'at, baik secara eksplisit maupun implisit, kemudian hikmah tersebut tersebut dijadikan pedoman dalam penetapan hukum. Para pakar maqashid mempercayai bahwa syari'at Islam diturunkan Allah SWT untuk membawa kemaslahatan bagi alam semesta. Karenanya, mereka tidak hanya berhenti pada pemahaman yang bersifat tekstual semata, tetapi juga mengadakan penelusuran pada makna dan tujuan yang tersuruk di balik hukum maupun 
berbagai dalil secara mendalam. (AlHasani, lsma'il, 1995, 123).

Namun perlu ditegaskan bahwa sekalipun maqa>shid dapat disebut ilmu yang bersendiri, akan tetapi dalam penetapan hukum ia tidak dapat diceraikan dari usul al-figh, karena kedua ilmu ini harus dikoneksikan dan dintegrasikan ketika penetapan hukum. Isma'il menyatakan:

$$
\text { "Pada hakikatnya maqashid }
$$

tidak bercerai secara resmi dari usul alfigh dalam proses penetapan hukum. Proses penggalian hukum tidak akan efektif dan paripurna kecuali mendalami aspek kebahasaan dan melakukan penelusuran aspek kemashlahatan yang diingini oleh syari'at. Demi tujuan integrasi kedua pengetahuan itu (maqshid dan istinbath hukum), kami rumuskan ilmu ushul yang berkiblat pada maqa>shid, yang mempunyai atensi terhadap hierarkis dalil, metode istinbat hukum, berbagai tujuan syari'at dan tata cara bagaimana memaksimalkannya dalam memahami shari>at. Apabila kesimpulan interpedensi kedua ilmu ini dapat diterima dalam ranah praktis, namun pada saat yang yang bersamaan kedua ilmu ini tetap berlainan dari sisi teoritis, baik aspek ontologis, metodologis maupun aksiologis. (Al-Hasani, Isma'il, 1995, 438).
Selaras dengan kesimpulan ini, al-Khadimi juga melihat terdapat koneksi yang kuat antara usul al-fiqh dan maqashid al-shariah (Ramadhina, 2020). jikalau pada permulaan bukunya ia menyatakana maqashid adalah usul min usul al-figh (fondasi dasar usul alfigh), (al-Khadimi, Nur al-Din, 1995, 7).

Pada bahagian lain ia mengatakan usul al hiya asas almaqashid (usul adalah fondasi dasar maqashid). Al-Hasani, Isma'il, 1995, 110). Koneksi kedua pengetahuan ini dapat kelihatan dari berbagai teori usu>l alfigh yang tidak dapat dipisahkan begitu saja dari teori maqashid al-shariah, seperti kemestian memehami maqashid dalam kajian ijtihad dan keharusan melakukan penelusuran makna terdalam atau maqa $>$ shid dalam bahasan dilalah al-alfadz.

Berdasarkan hal ini, dalam pandangan al-Khadimi, yang dimaksud istiqlal maqashid am al-usul al-figh (independensi/kemerdekaan maqashid dari usul al-figh) itu hanya berada pada ranah teoritis, sistematika pembahasan dan bahan kajian. Sementara dalam ranah praktis, kedua ilmu kawin dan tidak bisa diceraikan satu sama lain secara total. la memberi contoh pembedaan kedua ilmu ini ibarat perceraian usul al-figh dengan figh dan 
bahasan ibadah dengan mu'amalah. Dua hal yang kelihatan tampak berlainan dari dimensi materi dan sistematika pembahasan, akan tetapi pada hakikatnya kedua hal ini berhubungan. (Al-Khadimi, Nur al-Din, 2007, 110).

Sebenarnya, al-Sha>tibi sudah memaparkan relasi kedua pengetahuan ini, meskipun ia tidak memakai istilah maqashid dan usul al-figh secara langsung. Dia memberikan istilah maqashid dengan berbagai dalil umum (kulliyah), karena ia adalah kesimpulan umum dari semua aspek syariat. Sementara usul al-figh diberi istilah dengan dalil khusus karena ia berisi berbagai dalil yang bersifat parsial, juziyyah, dan teknis. Dalam perspektifnya, baik dalil umum maupun dalil khusus sangat penting diterapkan dan tidak boleh diabaikan salah satunya dalam proses penetapan hukum. (Ferdiansyah, Hengki, 2018, 62). Alshathibi berkomentar:

Adalah sebuah keharusan yang tidak dapat dibantah, yakni untuk memakai segala dalil universal ini (alkulliyat/maqashid al-shariah) dalam pemakaian berbagai dalil spesifik, semisal; al-Quran, hadis, ijma' dan qiyas, Orang yang hanya berpegang kepada berbagai dalil khusus dan berpaling dari berbagai dalil umum maka hasil ijtihadnya akan keliru dan begitu pula sebaliknya. (Al-sha>thibi, Abu lsha>q, t.t., 174).

Berdasarkan kutipan di atas, 'Ali lbn Rabi>'ah mengwajibkan untuk mengembalikan kepada berbagai dalil khusus (al-adillah al-juz'iyyah), seperti al-Quran, hadis, dan lain-lain, serta dikoloborasikan dengan maqashid alshariah ketika dilakukan penggalian hukum, bahkan mendasarkan kepadanya adalah sebuah keharusan dalam syariat disebabkan adanya dalil yang menguatkan hal ini. (Rabi'ah, Ali Ibnu, 2002, 281). Jika dlihat lebih lanjut, sekalipun Ibnu 'Ashu>r adalah orang yang mendiskursuskan maqashid menjadi ilmu yang berdiri sendiri, namun kelihatannya ia masih kosnsiten memakaikan usul al-figh dalam ranah praktis. Kesimpulan ini sangat kentara kelihatan dalam uraiannya yang berkaitan dengan ihtiyaj al-faqih ila ma'rifah maqashid al-shariah (urgensi maqashid alshariah bagi ahli figh). (Ferdiansyah, Hengki, 2018, 63).

Pada kajian ini, ia memaparkan bahwa ada lima tugas dan tanggung jawab bagi seorang mujtahid terhadap syari'at, salah satunya adalah mendapatkan pemahaman al-Quran dan hadis berdasrkan pendekatan linguistik. Untuk memgetahui penerapan pendekatan linguistik tersebut sesorang mesti mendapatkan pemahaman usu>l 
al-figh secara mendetail. Sementara empat tugas lainnya, seperti analis berbagai pertentangan dalil, pemakaian qiya $>$ s, metode penetapan hukum yang tidak ada dalilnya dan tidak dapat dianalogikan ke dalil manapun, dan melakukan penelusuran maksud dan tujuan hukum, adalah fungsi utama ilmu maqa>shid al-shari>ah. (Ibn 'Ashu>r, Al-Tha>hir, 2001, 13-16).

Penjelasan Ibn 'Ashur ini mengisyaratkan bahwa ushul al-figh memang tidak dapat dipandang sebelah mata begitu saja, ketika melakukan analisis sebuah persoalan, terutama untuk mendapatkan makan tekstual alQuran dan hadis, karena tidak mungkin mendapatkan pemahaman maksud dan tujuan syariat tanpa mengerti makna dasar teks terlebih dahulu. Oleh sebab itu, kedua ilmu itu harus saling terkoneksi dan terkoloborasi satu sama lain guna mendapatkan kesimpulan hukum yang lengkap dan kontributif. Mengabaikan salah satunya, pada gilirannya akan membangun pemahaman yang reduksionis, distorsi dan dikotomis. (Ferdiansyah, Hengki, 2018, 63).

Dari semua pendapat di atas, kelihatannya diskursus ulama mengenai status kajian maqa>shid tidak terlalu bertentangan dan masih dimungkinkan untuk mencari titik temunya. Pendapat yang mensupor independensi maqa>shid al-shariah pada hakikatnya lebih melihat pada dimensi bahasan, metode dan sistematika kajian maqa>shid yang memang sudah berkembang dan agak sedikit berlainan dengan bahasan usu>l al-figh. Sedangkan kelompok yang melakukan kritik wacana indepensi lebih memperhatikan ranah praktisnya, sebab sudah dijelaskan sebelumnya bahwa kedua ilmu ini sangat dibutuhkan ketika penggalian hukum. Kendati demikian, kelompok ini juga tidak memicingkan mata dengan perkembangan kajian maqa>shid yang begitu cepat dan signifikan, bahkan sebahagian mereka julga menulis buku khusus dan spesifik tentang maqa>shid, sebut saja Jama>l alDi>n al-Athiyyah, 'Abdullah lbn Ba>yah ,Ahmad al-Raysuni, Ali Jum'ah, llya $>$ s Dardu $>r$ dan lain-lain. Oleh karena itu, dapat disimpulkan bahwa mazhab interpedensi merupakan jalan tengah dari kedua pendapat sebelumnya. (Ferdiansyah, Hengki, 2018, 64).

\section{Maqashid al-Shariah di zaman Sahabat \\ Embrio teori maqashid atau} substansi maqa>shid dapat ditemukan semenjak zaman Nabi dan sahabat. Namun ketika belum ditulis menjadi ilmu yang berdiri sendiri atau bahagian usu>l ak-figh. ( Rohayana, Muhtarom, 2021). Imam Ahmad (w.241 H/847 M) meriwayatkan bahwa "ketika sahabat 
menemukan permasalahan baru dan mereka tidak mendapatkan dasar landasan hukumnya dalam al-Quran dan hadis, maka mereka akan menerapkan ra'yu dengan menggunakan metode qiyas (analogy). Metode ra'y dan qiya>s disimpulkan oleh Ima>m Ahmad mengcover unsur maqa>shid. Walaupun demikian ijtihad yang dirumuskan harus cocok dengan apa yang diingin oleh shari' (pembuat syari>'ah). Jasser Audah menulis mencatat beberapa kejadian yang mengisyaratkan adanya nilai maqa>shid. (Audah, Jasser, 2011, 31).

Pertama, hadis sharih tentang perintah Rasulullah kepada beberapa sahabat untuk mengadakan perjalanan ke Bani Quraizah dan agar melaksanakan salat ashar setelah sampai di sana. Karena perjalanan ke sana jaraknya cukup jauh dan menghabiskan waktu. Sebahagian sahabat ketika itu berbeda pendapat dalam memahami perintah Rasullah. Sebahagian sahabat tetap meneruskan perjalanan dan shalat akan dilakukan setelah sampai disana. Namun sebahagian sahabat yang lain melaksanakan salat Ashar di perjalanan karena takut keburu masuknya waktu salat magrib. Bunyi teks hadis di atas adalah:

عن ابن عمرو رضي الله عنهما أنه قال: قال النبي صلى الله عليه وسلم لنا لما رجع من الأحزاب: لايصلين أحد العصر إلافي بني

$$
\begin{aligned}
& \text { قريظة, فأدرك بعضهم العصر في الطريق, فقال } \\
& \text { بعضهم: لاتصلين حنى ناتها, وقال بعضهم:بل فيل } \\
& \text { نصلى! لم يردمنا ذاللك (أى أنه أراد الإسراع وهاع ). } \\
& \text { فذكر للنبي صلى الله عليه وسلم فلم يعنف واحدا } \\
& \text { منهم. (رواه البخاري). }
\end{aligned}
$$

Artinya:

Dari Ibn 'Umar ra. ia berkata. Nabi Saw kepada kami tatkala kami baru sampai dari berbagui parit: seseorang hendaknya jangan shalat kecuali jika sudah sampai di Bani Quraizah. Lalu sebahagian mereka masih diketahui berada di jalan. Lalu sebahagian mereka berpendapat: kita tidak akan melakukan shalat hingga sampai di Bani Quraizah. Sementara yang lain berpendapat: tetapi kita mesti melakukan shalat! kita tidak ingin yang demikian (artinya ingin cepat-cepat sampai disana). Lalu menceritakanlah salah seorang dari mereka, lalu Rasulullah tidak mencela salah seorangpun dari mereka. (H.R. Bukha>ri). (Bukha>ri, Muhammad, 1407, 321).

Sedangkan dalam riwayat Ima $>\mathrm{m}$ Muslim sebagai berikut:

$$
\begin{aligned}
& \text { وقال الأخرون:لا نصلى إلا حيث أمرنارسول } \\
& \text { الله صلى الله عليه وسلم و إن فاتنا الوقت. (رواه اهل }
\end{aligned}
$$

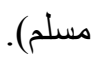

Artinya:

Sahabat yang lain berkomentar: Tidaklah kami shalat kecuali berdasarkan yang telah Rasulullah 
perintahkan kepada kami, sekalipun waktu telah meninggalkan kami. (H.R . Muslim). (Muslim, Ibn Hujaij, 1931, 291. Kelompok pertama, melaksanakan sesuai dengan instruksi Nabi apa adanya alias tekstual. Sedangkan kelompok kedua melakukan rasionalisasi terhadap perintah Rasul yang menunjukan adanya maqa $>$ shid yakni bukan lafaz amar pada perintah salatnya, lafaz amar untuk sampai di Bani Quraizah.

Kedua, tentang kebijakan Khalifah 'Umar lbn Khatha>b yang enggap dalam mendistribusikan wilayah yang ditaklukan di sebahagian Mesir dan Iraq kepada para sahabat. Para sahabat meminta kepada khalifah untuk mendapatkan sebahagaian wilayah taklukan. Permintaan para sahabat tersebut didasari berangkat dari ayat alQuran yang membolehkan mengambil sebahagian dari harta rampasan perang. Mereka mendasarkan pendapat mereka kepada QS. al-Fath (48) ayat 20.

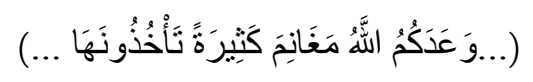

Artinya:

"Allah menjanjikan kepada kamu harta rampasan yang banyak yang dapat kamu ambil...," (QS. al-Fath , 48: 20).

Namun permintaan itu ditolak dengan tegas oleh Khalifah Umar bin Khatha $>b$ dengan menggunakan ayat alQuran dalam surat al-Hashar ayat 7.

$$
\text { (...كي لايكون دولة بين الأغنياء منكم...) }
$$

Artinya:

“...supaya harta itu jangan beredar diantara orang-orang kaya saja di antara kamu..."(Al-hashr, 59:7).

Sebenarnya ayat yang dijadikan dasar penolakan oleh Khalifah 'Umar bin Khatha>b ini, bermakna lebih umum bila dibandingkan dengan ayat yang dipakai oleh para sahabat yang lebih bermakna khusus. Namun ayat yang dipakai Umar sebagai alasan argumentasi mengandung makna bahwa pembuat hukum (al-sha>ri) mempunyai tujuan (maqa>shid) yakni agar tidak terjadi dominasi dan monopoli harta kekayaan oleh orang tertentu yakni umat Islam yang menaklukan sebahagian daerah Mesir dan 'Iraq. ljtihad ini mengisyaratkan bahwa tujuan hukum yang lebih tinggi harus didahulukan dari sekedar memahami secara harfiah (literal).

Ketiga, pelaku pencurian di dibatalkan hukuman potongan tangan oleh Umar bin Khathab dan bertentangan dengan zhahir ayat dalam QS. al-Maidah, 5 ayat: 38 .

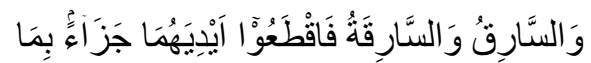

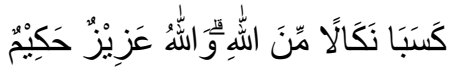

Artinya:

Adapun orang laki-laki maupun
perempuan yang mencuri, potonglah
tangan keduanya (sebagai) balasan atas 
perbuatan yang mereka lakukan dan sebagai siksaan dari Allah. Dan Allah Mahaperkasa, Mahabijaksana. (QS. Almaidah, 5: 38).

Khalifah Umar bin Khatha>b mengerti bahwa potong tangan itu adalah perintah yang tegas dalam alQuran diatas. Namun Khalifah Umar bin Khatha $>\mathrm{b}$ menyadari bahwa pencuri itu melakukan tindakan kriminal, karena telah terjadi kelaparan di tengah suasana ekonomi lagi morat-marit yang menghimpit penduduk Madinah. Oleh karena itu menetapkan hukuman kepada seorang pencuri dalam keadaan terdesak yakni untuk mempertahankan jiwa untuk hidup, adalah bertentangan dengan nilai-nilai keadilan yang menjadi dasar utama penetapan hukum dan juga tidak membawa kemaslahatan.

Keempat, Umar bin Khathab tidak memberikan jatah pendistribusian zakat kepada orang yang baru masuk Islam. Padahal orang yang baru masuk agama Islam memiliki hak yang sama dengaan ashaf yang lain dan sesuai dengan kandungan di dalam QS. alTaubah (9) ayat 60.

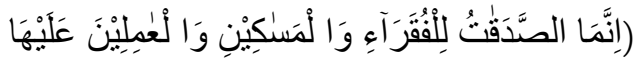

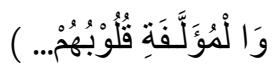

Artinya:

"Sesungguhnya zakat itu hanyalah untuk orang-orang fakir, orang miskin, amil zakat, yang dilunakkan hatinya (mualaf)... (QS. At-Taubah 9: Ayat 60). Khalifah 'Umar bin Khatha>b memahami ayat diatas tidak secara harfiah. Umar melihat latar belakang kenapa di zaman Rasulullah para pemeluk baru agama lslam diberi secara jelas, demi untuk melunakan hati mereka. Mereka diberi zakat karena secara kwantitas umat Islam ketika itu masih kurang. Padahal Islam ketika itu membutuhkan kwantitas dan akibatnya , ditakutkan mereka akan keluar meninggalkan agama Islam, yang baru mereka peluk. Akibatnya Islam akan menjadi lemah. Namun tujuan pemmberian zakat kepada pemeluk baru itu tidak ditemukan lagi di era sahabat, khususnya era Umar. Karena secara kwantitas umat Islam sudah banyak, bahkan Islam sudah menyebar ke luar Arab yakni Persia, Mesir dan berbagai daerah lain. Maka dipahami Umar melakukan ini karena melihat maqashid yang mengandung mashlahat untuk tidak memberikan jatah kepada pemeluk agama baru Islam.(Isnaini, 2018, 206-218)

\section{KESIMPULAN}

Berdasarkan analisis dan pengkajian terhadap penerapan maqashid al-shari>ah dapat ditarik kesimpulan sebagai berikut: 
1. Maqashid al-shariah telah ditemukan benih-benih di zaman sahabat, ketika mereka menyelesaikan berbagai persoalan hukum. Mereka menyelesaikan berbagai kasus selalu bersumber kepada al-Quran dan hadis. Namun mereka memahami al-Quran hadis secara tekstual dan kontekstual dengan memperhatikan tujuan, rahasia, hikmah, sebab dan berbagai penyebab ditetapkan hukum. Sahabat selalu mengacu kepada tujuan al-Sha>ri' dalam penetapan hukum yaitu kemashlahatan yakni mencari mashlahat dan menolak kemafsadatan.

2. Berbagai contoh penerapan maqa>shid al-shariah missal kasus pembatalan potong tangan, pembahagian zakat kepada pemeluk baru agama lslam, distribusi zakat serta memutuskan shalat di tengah perjalanan atau setelah sampai di tujuan, mereflesikan tujuan, rahasi, hikmah dan sebab al-sha $>$ ri menetapkan hukum.

\section{DAFTAR PUSTAKA}

Abadi, Al-Fayru>z, 1987, Al-Qamus alMuhith. Beiru>t: Muassasah alRisalah.

Bukha>ri, Muhammad Ibn Isma>il alJa'fari, 1407, (Beiru>t: Da>r lbn Katsir wa al-Yamamah).

Daraz, 'Abdullah, dalam al-Shathibi, Abu Isha $>q$ al-Muwafaqat $\mathrm{Fi}$
Uu>l al-Shari>'ah, (Biru>t: Da $>r$ al-kutb al-'llmiyyah).

Dardu<r, llyas, (2010), Muhadharat Maqashid al-Shariah, Beirut: Dar lbn Hazm.

Al-fahri, 'Alla>l Ibn 'Abdullah al-Wa>hid Ibn 'Abd al-Salaam Ibn 'Alla>L al-fasi, 1963, Maqashid alShariah al-lslamiyyah wa Maka>rimuha, (Kairo: Da>r alSala $>\mathbf{m})$.

Ferdiansyah, Hengki, 2017, Pemikran Hukum Islam Jasser Auda, (Ciputat: Yayasan Pengkajian elBukhori).

Al-Hasani, lsma'il, 1995, alNazahariyyah al-Maqashid Ind al-lmam Muhammad al-thahir Ibn 'Ashur, (Herndon: IIIT).

Ibn 'Ashur, al-Thahir, 2006, $A$ maqa>shid li al-hariah alIslamiyyah, (Kairo: Da>r alSalam).

Ibn Hirzillah, 'Abd al-Qadir, 2007, Dhawabith l'tibar al-Maqashid, (Riyadh: Maktabah al-Rush).

Isnaini, 2018, “Mashlah Al-Mursalah Sebagai Dalil Hukum dan Metode ljtihad, dalam jurnal Hikmah.ljournal of IslamicStudies, 16 (2), 2020, 203-218 Htttp://journal.alhikmah jkt.ac.id/index.php/Hikmah.

Jughaim, Nu'ma>n, 2007, “Al-'ala>qah Bayn Maqashid al-Shari'ah wa Usul al-Fiqh",Majallah, Vol. 4, No.2.

Al-khadimi. Nur al-Din Mukhta>r, 2008, Abha>ts fi Maqa>shid alShari>ah Dira>sah Maqa>shidiyyah Liba'dh Qadha>ya al-ijtiha>di wa alTajdi>d wa al-Mu'>shirah wa alFikr wa al-Hadha>rah wa alThaqa>fah wa al-Mnathiq wa alUsu>l wa al-Furu>', (Beiru>t: Muassasah al-Ma'arif li alThaba>'ati wa al-Nashr).

Muslim, Ibn Hujaij 1931,Shahih Muslim, (Beiru>t: Da $>r$ al-A $>f a>q)$. 
Munawwir, Ahmad Warson, 1997, Kamus Al-munawwir Kmaus Arab Indonesia, (Surabaya: Pustaka Progressif).

Al-najja $>$ r, 'Abdul al-Ma>jid, 2008,23

Rabi'ah, 'Abd al-'Azi>z 'Ali lbnu, 'llm Maqa>shid al-Sha>ri', (Riya $>$ dh: Mamlakah al-'Arabiyyah, alSu'u>diyyah.

Ramadhina, A., \& Yunus, Y. (2021). KORELASI PENDIDIKAN DAN USHUL FIQH DALAM KONSEP ISTISHLAH DAN SADD DZARl'AH. Jurnal Kajian Agama Hukum dan Pendidikan Islam (KAHPI), 2(2), 15-25.

Rohayana, Ade Dedi, and Ali Muhtarom. "Islamic Jurisprudence Implementation in Indonesia: Perspective of the Objectives of Islamic Law." Global Jurist, 2021. https://doi.org/10.1515/gj-20200078.

Shahi>d, al-Hasan, 2013, al-Khitaha>b alMaqa>shidi al-Mu'a>shirah, (Beirut: Nama).

Zahgibah, al-Din lzz al-Din lbn Abd alSalaam, 1999, Al-maqa>shid $l i$ al-hari>ah al-lsla>miyyah, (Kairo: Dar al-Shafwah).

DOI:10.4.47466/Hikmah.vl6i2.1751 PISSN.2088-2629, E-ISSN,25810146. 